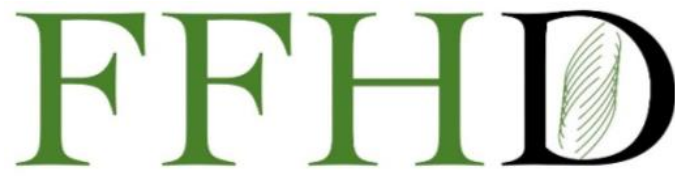

Functional Foods in Health and Disease

\title{
Effects of 5-aminolevulinic acid on production of antibodies against classical swine fever live vaccine
}

\section{Eiji Kobayashi* $^{*}$}

Department of Kidney Regenerative Medicine, Industry-Academia Collaborative Department, The Jikei University School of Medicine, Tokyo, Japan

*Corresponding author: Eiji Kobayashi, MD, PhD, Department of Kidney Regenerative Medicine, IndustryAcademia Collaborative Department, The Jikei University School of Medicine, 3-25-8 Nishi-Shimbashi, Minato-ku, Tokyo, Japan

Submission Date: August 20 th 2021 ; Acceptance Date: October 26 ${ }^{\text {th }}, 2021$; Publication Date: November $3^{\text {rd }}, 2021$

Please cite this as: Kobayashi E. Effects of 5-aminolevulinic acid on production of antibodies against classical swine fever live vaccine. Functional Foods in Health and Disease 2021; 11(11): 548-558. DOI: https://www.doi.org/10.31989/

ffhd.v11i11.838

\section{ABSTRACT}

Introduction: The aim of this study was to examine the effects of a bioactive compound, 5-aminolevulinic acid (5-ALA), which has been reported to exhibit an immune-boosting effect, using a classical live swine fever (CSF) vaccine experimental model in pigs.

Methods: First, the effect of two different 5-ALA doses was evaluated by measuring the blood CSF viral load in male and female micro miniature pigs after vaccination with live vaccines. The CSF vaccine had a low inducing effect on antibody production in females, which improved after administration of 5-ALA by enhancing Th2 immunity as indicated by elevated interleukin-10 levels. Next, using male micro miniature pigs, the change in body weight was measured from the time before inoculation with the live vaccine to 28 days after inoculation, and the pattern of IgM and IgG antibody production after 5 ALA administration was examined.

Results: Preventive doses of 5-ALA enabled the continuous production of IgG antibodies at the same rate as found in control pigs not receiving 5-ALA; however, the switch to IgG production was delayed during 5-ALA treatment. Oral administration of 5-ALA kept the testing male pigs healthy, showing normal growth. 
Conclusions: This suggested that the heme synthesis-promoting effects of 5-ALA simultaneously promoted the conversion of B cells into plasma cells.

Keywords: functional food, 5-ALA, human equivalent dose, pig, classical swine fever

\section{Possible Immunity of 5-ALA Against Vaccine Virus}

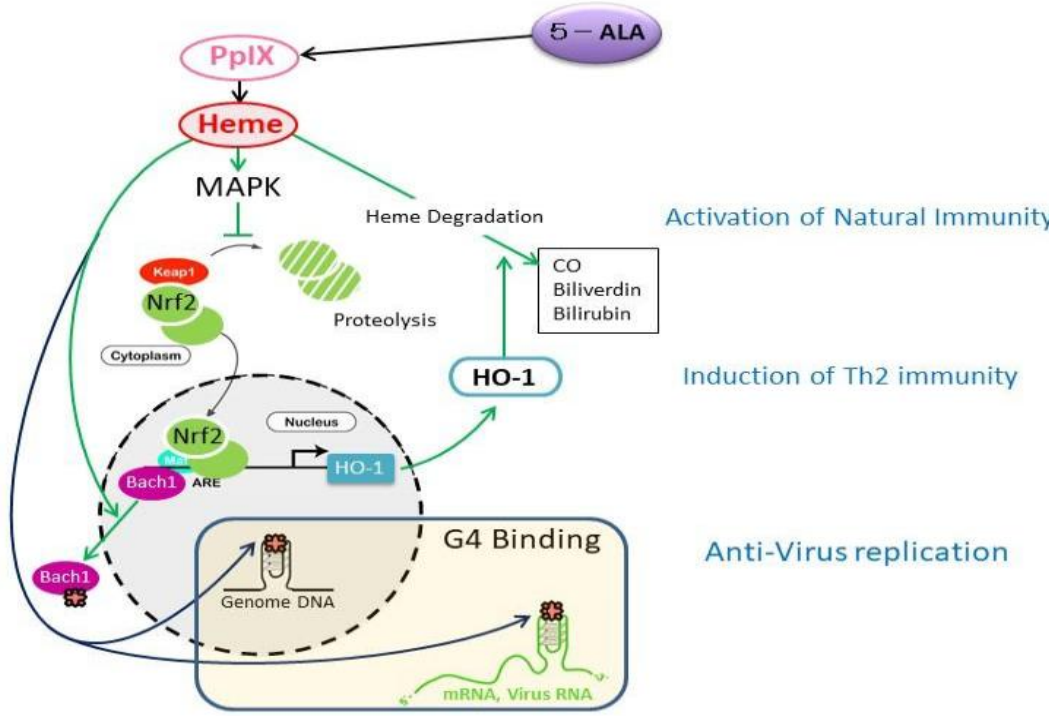

CFFC 2021. This is an Open Access article distributed under the terms of the Creative Commons Attribution 4.0 License (http://creativecommons.org/licenses/by/4)

\section{INTRODUCTION}

Five-aminolevulinic acid (5-ALA) is a natural amino acid found in mitochondria, which produces energy in all living organisms, including animals, humans, and plants. 5-ALA is converted to protoporphyrin IX (PPIX) in cells and forms a complex with iron in animals, subsequently forming heme, which is a component of hemoglobin, an oxygen carrier. In plants, magnesium is incorporated into chlorophyll, and 5-ALA is the source of chloroplasts that are essential for plant photosynthesis. Given this beneficial heme-forming ability, 5-ALA has been widely used for treating several human diseases and for metabolic improvement, such as hyperglycemia and sleep disorder in the form of a bioactive compound [1-2].

ALA was known to be effective against infectious diseases such as malaria due to its modification into PPIX in the body [3-4] and its ability to target the $G 4$ protein [5]. Notably, the G4 protein complex was recently identified to have antiviral effects [6]. Further, 5-ALA has been demonstrated to be vital for the prevention and treatment of influenza in mouse models (SBI Pharma,

Patent Application 2012-160999 WO2014013664A1) and in studies involving viruses infecting whiteleg shrimp (Litopenaeus vannamei) [7].

The world is currently in the throes of a pandemic caused by the novel coronavirus SARS-CoV-2, a positivesense single-stranded RNA virus originating in bats [8]. Although a recent study indicated that swine are susceptible to low levels of SARS-CoV-2 viral infection [9], conducting in vivo challenge experiments with SARS-CoV2 is not feasible. To determine the human equivalent dose of 5-ALA, in this study, a classical swine fever (CSF) live vaccine model was used to examine the effects of 5ALA on antibody production, an important part of the infection establishment process.

This study can pave the way to facilitate better 
understanding of the human equivalent dose of 5-ALA and of potential viral transmission between humans and pigs [9-11].

\section{MATERIALS AND METHODS}

This study was performed at an AAALAC internationalapproved facility. The animals were handled in accordance with the guidelines of Animal (Scientific Procedures) "Ministerial Ordinance on Good Laboratory Practice for Nonclinical Safety Studies of Drugs" (Ordinance of Japan's Ministry of Health and Welfare No. 21 of March 26,1997, as last amended by the ordinance of Japan's Ministry of Health, Labor and Welfare No.114 of June 13, 2008). The experimental protocol was approved by the Animal Care and Use Committee of Hamri Co., Ltd. [approval no: 20-H050 \& 20-H064].

Experimental animals and pharmacological agents: For the first experiment, 6 male and 6 female micro miniature pigs (MMP), aged 52-55 days and born at the same time in the same facility (Fuji Micra Co., Ltd, Shizuoka, Japan), were used. The males and females were each divided into three groups ( $n=2$ per group): the normal-feed group (control group), low-dose group (5 mg a)

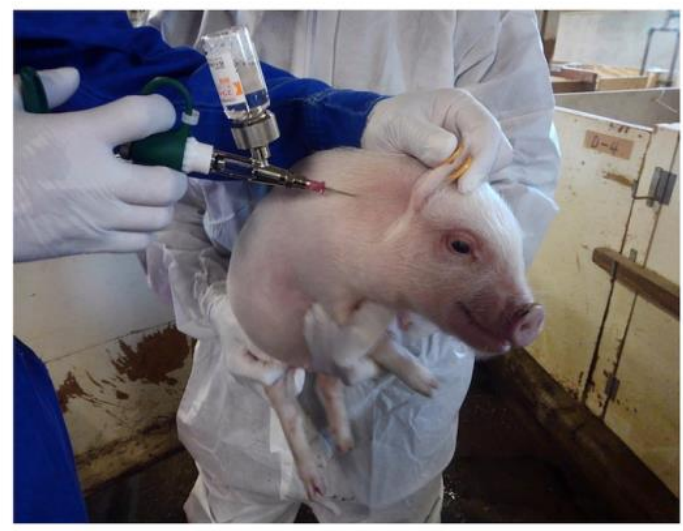

$5-\mathrm{ALA}-\mathrm{HCl}+3.9 \mathrm{mg} / \mathrm{kg}$ sodium ferrous citrate [SFC]), and high-dose group (50 mg 5-ALA-HCL $+39 \mathrm{mg} / \mathrm{kg} \mathrm{SFC}$ ) (molar ratio of ALA:SFC $=1: 0.25$ ). The second experiment involved 8 male micro miniature pigs, aged 52-55 days, divided into two groups ( $n=4$ per group): the normalfeed group (control group) and the 5-ALA group (50 mg $5-\mathrm{ALA}-\mathrm{HCl}+39 \mathrm{mg} / \mathrm{kg} \mathrm{SFC}$ ).

5-ALA and SFC were separately mixed into small amounts of normal feed, rolled into balls, and fed to the pigs before their morning meal, followed by their regular feed. This was done once daily, starting from four days before vaccine administration (Day -4 ) to 28 days after vaccine administration (Day 28).

CSF live vaccine: One vial of dried vaccine (for 20 animals) containing at least $10^{4.3}$ median tissue culture infectious disease dose $\left(\mathrm{TCI}_{50}\right)$ of the attenuated $\mathrm{GPE}^{-}$strain of the CSF virus (seed) in guinea pig kidney cell culture was used. The included solvent solution was used to dissolve the dried vaccine, and $1 \mathrm{~mL}$ of vaccine solution was inoculated either subcutaneously or intramuscularly into the pigs (Figure 1a). All animals were inoculated once at 56-59 days of age (Day 0).

b)

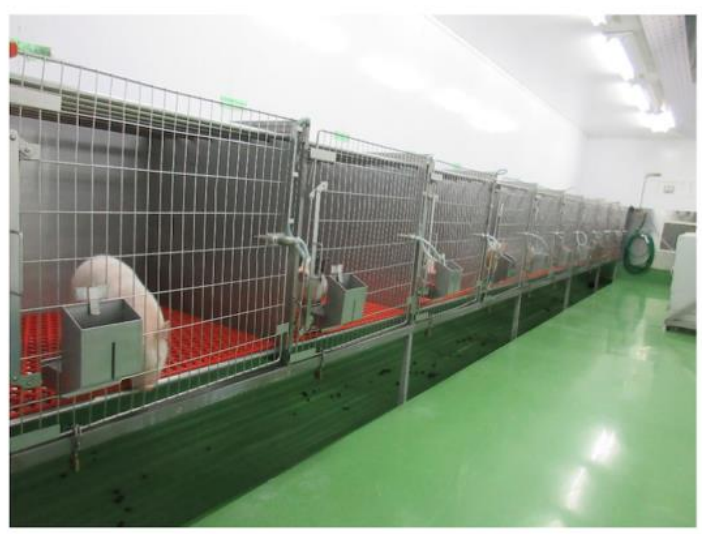

Figure 1. Microminiature pigs used in this study

a) MMPs aged 56-59 days were inoculated once by subcutaneous or intramuscular administration of CSF virus vaccine. b) MMPs were individually bred in a clean breeding environment at the AAALAC certified facilities.

Observation and testing: The change in body weight was measured from the time before inoculation with the live vaccine to 28 days after inoculation in the second experiment. An increase or decrease in body weight over time was observed relative to a standard growth curve (listing mean weights, +1 SD, and +2 SD) for microminiature pigs, as determined by the Shizuoka Prefecture Small and Medium Livestock Center $(n=23)$.

MMPs had been originally established in Japan as very small experimental miniature pigs [14]. MMPs were 
fed using regular food of ATTACK KOBUTA produced by Marubeni Nisshin Feed Co., Ltd. (4-5-1 Muromachi, Nihonbashi, Chuo-ku, Tokyo, Japan). As the body weight of pigs is known to be dependent on diet, the feed is shown in Table 1. During the 5-ALA experiments, $70 \mathrm{~g} / \mathrm{head}$ of the feed was given twice a day (Total 140g/Day).

Table 1. Ingredients details of ATTAKBKOBUTA for testing MMPs

\begin{tabular}{|c|c|c|}
\hline Ingredients Type & Ratio (\%) & Name of the ingredients \\
\hline \multirow[t]{2}{*}{ Foodgrain } & 72 & corn, precooked corn, milo, common wheat, brown rice, bread crumbs, (flour) \\
\hline & & soybean oil cake, rapeseed oil cake \\
\hline plant-derived oil cake & 22 & rice bran, bran, (DDGS; corn distillers grains with soluble), (corn gluten feed) \\
\hline plant-derived chaff and bran & 2 & fish meal, (mixed feed of pork \& chicken) \\
\hline animal-derived feed & 1 & molasses, animal fat, sweets crumb, calcium carbonate, salt, lactic acid \\
\hline others & 3 & 1, पived \\
\hline
\end{tabular}

Antibody production in the blood was used as an index of infection establishment. After inoculation with the CSF live vaccine, the microminiature pigs were reared at Hamri Co., Ltd. (Ibaraki, Japan). Approximately $5 \mathrm{~mL}$ of blood was collected from the jugular veins of the tested pigs at 14, 28, and 42 days after inoculation (Figure 1 b).

Anti-CSF antibody titers in the pigs' blood were quantified for both the IgM and IgG subtypes using enzyme-linked immunosorbent assay (ELISA) with CSF ELISA Kit II (JNC Corporation, Tokyo, Japan) according to the manufacturer instructions. IgM was inactivated (decomposed) upon mercaptoethanol treatment, and the level detected in the treated serum measured using the kit was taken as the IgG value. Absorbance was measured at a wavelength of $450 \mathrm{~nm}$, and the S/P value of the test serum was calculated using the following formula:

$$
S / P=[S(P)-S(N)] /[P C(P)-P C(N)]
$$

where $P C(P)$ is the average absorbance of positivecontrol serum in antigen-coated wells, $\mathrm{PC}(\mathrm{N})$ is the average absorbance of positive-control serum in antigen non-coated wells, $S(P)$ is the absorbance of the test serum in antigen-coated wells, and $S(N)$ is the absorbance of the test serum in antigen non-coated wells.
In addition, the S/P value of IgM was determined as described above by subtracting the S/P value of the serum treated with mercaptoethanol from the S/P value of the serum obtained before the treatment. Serum interleukin (IL)-4 and IL-10 levels were measured using an ELISA Kit (Cloud Clone CO., Wuhan, China). The blood CSF viral load was measured using the CSFV Real-time PCR kit (Kogene Biotech CO., Seoul, Korea).

\section{RESULTS}

Increase in the serum levels of IgM and IgG antibodies in response to the CSF live vaccine: In the first experiment, the CSF virus was detected on Day 3 or Day 14, and anti-CSF antibodies were detected on Day 28 and Day 42 after inoculation in the male control subjects (\#4552 and \#4556, Table 2). In contrast, in the female control subjects, CSF virus was not detected and the levels of the antibodies against CSF were very low (\#4550 and \#4551, Table 1). Administration of $50 \mathrm{mg}$ of 5-ALA for one month drastically induced antibody production on Day 28 or Day 42 in the females (\#4548 and \#4549). In addition, an increase in serum IL-4 and IL-10 levels was observed in a few cases of 5-ALA-treated individuals (Table 2). 
Table 2. Antibody production of micro mini pigs inoculated with classical swine fever (CSF) virus vaccine.

Male

\begin{tabular}{|c|c|c|c|c|c|c|c|c|}
\hline & \multirow[b]{2}{*}{ Subject } & \multirow[b]{2}{*}{ No. } & \multicolumn{2}{|c|}{ Control } & \multicolumn{2}{|c|}{$5 \mathrm{mg}$} & \multicolumn{2}{|l|}{$50 \mathrm{mg}$} \\
\hline & & & 4552 & 4556 & 4553 & 4554 & 4555 & 4557 \\
\hline \multirow[t]{3}{*}{ CSF virus Day3 } & & - & + & + & + & + & + & \\
\hline & Day14 & & + & - & - & - & - & - \\
\hline & Day42 & & - & - & - & - & - & - \\
\hline \multirow[t]{3}{*}{$\lg M+\lg G$} & Day14 & & 0.007 & 0.002 & 0.080 & -0.003 & -0.001 & -0.001 \\
\hline & Day28 & & 0.123 & 0.194 & 0.331 & 0.051 & 0.141 & 0.127 \\
\hline & Day42 & & 0.369 & 0.450 & 0.291 & 0.291 & 0.179 & 0.228 \\
\hline \multirow[t]{4}{*}{$\mathrm{IL}-4[\mathrm{pg} / \mathrm{mL}]$} & Day3 & & $<15$ & 142 & 80 & 250 & 68 & 166 \\
\hline & Day14 & & 106 & 121 & 178 & 160 & 26 & 186 \\
\hline & Day28 & & 175 & $<15$ & 85 & 296 & 131 & 158 \\
\hline & Day42 & & 132 & 15 & 123 & 290 & 74 & 299 \\
\hline \multirow[t]{4}{*}{ IL-10[pg/ml] } & Day3 & & 607 & 1675 & 768 & 2253 & 1599 & 1267 \\
\hline & Day14 & & 1062 & 1016 & 682 & 1378 & 2136 & 816 \\
\hline & Day28 & & 1289 & 359 & 1356 & 3017 & 2516 & 2083 \\
\hline & Day42 & & 359 & 780 & 1289 & 3381 & 1142 & 1762 \\
\hline \multicolumn{9}{|l|}{ Female } \\
\hline & & & \multicolumn{2}{|c|}{ Control } & \multicolumn{2}{|c|}{$5 \mathrm{mg}$} & \multicolumn{2}{|c|}{$50 \mathrm{mg}$} \\
\hline & \multicolumn{2}{|c|}{ Subject No. } & 4550 & 4551 & 4563 & 4564 & 4548 & 4549 \\
\hline \multirow[t]{3}{*}{ CSF virus } & Day3 & & - & - & + & - & - & + \\
\hline & Day14 & & - & - & - & - & - & - \\
\hline & Day28 & & - & - & - & - & - & - \\
\hline \multirow[t]{3}{*}{$\lg M+\lg G$} & Day14 & & 0.004 & 0.002 & 0.003 & 0.000 & 0.000 & 0.016 \\
\hline & Day28 & & 0.005 & 0.017 & 0.021 & 0.019 & 0.022 & 0.221 \\
\hline & Day42 & & 0.003 & 0.112 & 0.028 & 0.027 & 0.351 & 0.391 \\
\hline \multirow[t]{4}{*}{ IL-4[pg.mL] } & Day3 & & 92 & 27 & $<15$ & 31 & 67 & 22 \\
\hline & Day14 & & $<15$ & 58 & $<15$ & 166 & 48 & $<15$ \\
\hline & Day28 & & $<15$ & $<15$ & $<15$ & 101 & 167 & 414 \\
\hline & Day42 & & 67 & 227 & 139 & 410 & 75 & $<15$ \\
\hline \multirow[t]{4}{*}{ IL-10[pg/mL] } & Day3 & & 1131 & 317 & 1895 & 1857 & 645 & 707 \\
\hline & Day14 & & 479 & 1478 & 976 & 2771 & 372 & 153 \\
\hline & Day28 & & 230 & 816 & 1258 & 1119 & 2421 & 2913 \\
\hline & Day42 & & 657 & 1729 & 1159 & 2832 & 1345 & 1017 \\
\hline
\end{tabular}

CSF virus status (positive/negative) confirmed by RT-PCR; levels of anti-CSF virus antibodies and cytokines are shown for each individual in the first experiment.

Table 3. Levels of anti-CSF virus antibodies (IgM and IgG) for each individual in the second experiment

Male

\begin{tabular}{|c|c|c|c|c|c|c|c|c|c|}
\hline \multirow[b]{2}{*}{ Subject No. } & \multicolumn{5}{|c|}{ Control } & \multicolumn{4}{|c|}{$50 \mathrm{mg}$} \\
\hline & & 4529 & 4530 & 4534 & 4537 & 4528 & 4533 & 4535 & 4536 \\
\hline \multirow[t]{3}{*}{$\lg M$} & Day14 & -0.031 & -0.014 & -0.003 & -0.001 & -0.036 & 0.003 & -0.005 & -0.027 \\
\hline & Day28 & 0.968 & 0.355 & 0.341 & 0.559 & 0.847 & 0.627 & 0.386 & 0.861 \\
\hline & Day42 & 0.159 & 0.147 & 0.302 & 0.330 & 0.276 & 0.233 & 0.313 & 0.353 \\
\hline \multirow[t]{3}{*}{$\lg G$} & Day14 & 0.098 & 0.016 & 0.012 & 0.005 & 0.047 & 0.003 & 0.009 & 0.017 \\
\hline & Day28 & 0.030 & 0.115 & 0.559 & 0.329 & -0.005 & -0.005 & 0.152 & 0.000 \\
\hline & Day42 & 0.558 & 0.161 & 0.327 & 0.225 & 0.360 & 0.152 & 0.177 & 0.404 \\
\hline
\end{tabular}


As described above, in the male control group, the CSF virus was detected 14 days after vaccination, suggesting that males are more susceptible to the virus than females. In addition, both IL-4 and IL-10 levels tended to be higher in the 5-ALA administration groups (\#4554, \#4555, and \#4557, Table 2). Therefore, IgG and IgM were separately examined for antibody production in males in the next experiment.

Anti-CSF IgM was not detected in either the control or 5-ALA group at Day 14, although it was detected at the same level in both groups at Day 28 (Table 3). The fact that antibody-based immunity had been elicited in all animals indicated that the CSF live vaccine had successfully established a CSF infection. By contrast, antiCSF IgG levels followed a different pattern (Table 3): antiCSF IgG was not detected in either group at Day 14 , and

a)

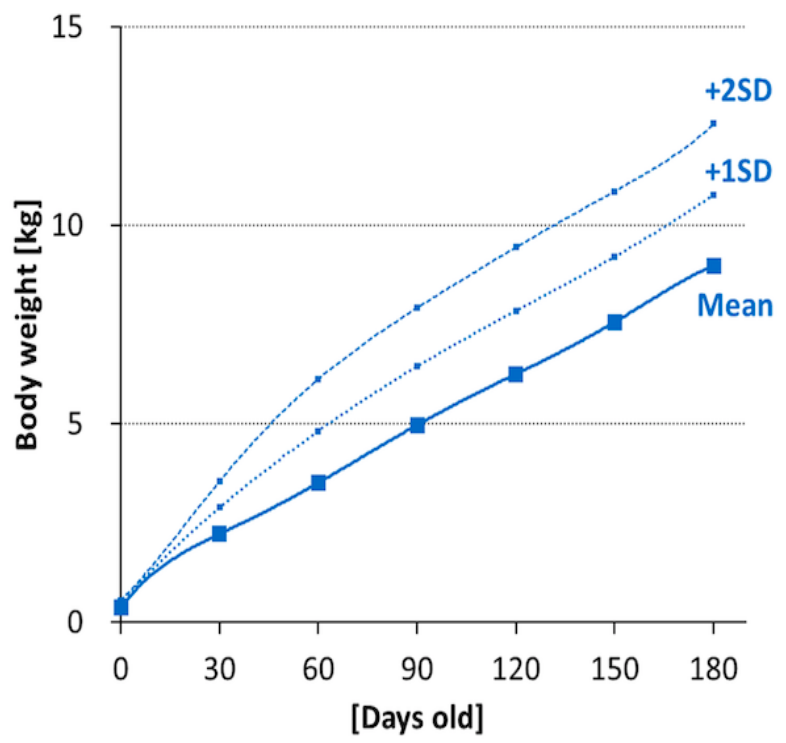

its levels increased over time in the control group but not in the 5-ALA group.

Changes in weight: Changes in the body weight of the animals in both the 5-ALA and control groups in the second experiment are shown in Figure $2 \mathrm{~b}$. In terms of the growth rate, 3 of 4 pigs in the 5-ALA group (\#4533, \#4535, \#4536) were below the +1 SD curve prior to the administration of 5-ALA (at 45-48 days of age; Day -11); however, after administration of 5-ALA (at 66-69 days and at 84-87 days of age; Day 10 and Day 28, respectively), the data points were above the +1 SD curve. In other words, these three pigs grew faster, showing a growth rate higher than the standard growth rate. A similarly accelerated growth rate pattern was observed for only one out of four pigs in the control group (\#4530).

b)

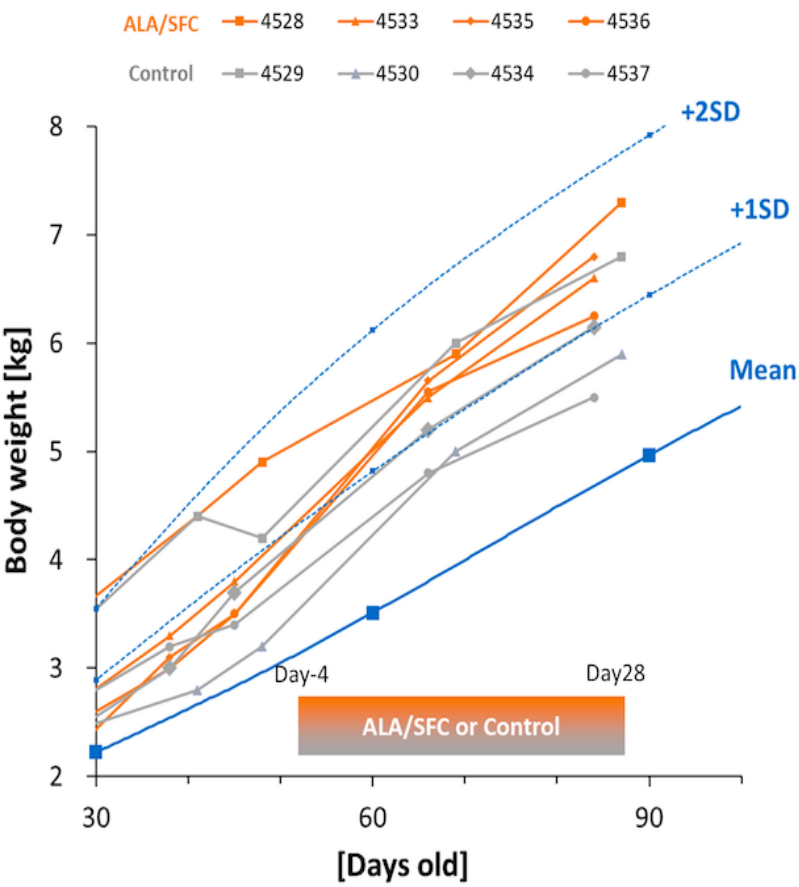

Figure 2. Body weight gain of MMPs

a) The standard growth curve of MMPs. The body weight of MMP ( $n=23)$ bred at Shizuoka Prefectural Research Institute of Animal Industry, Swine \& Poultry Research Center was measured every 30 days. The average value, $+1 S D$ and +2 SD values were plotted (blue). b) The body weight of each MMP in the ALA/SFC administration group (\#4528, \#4533, \#4535, \#4536, orange) and the control group (\#4529, \#4530, \#4534, \#4537, gray) was plotted on the standard curve (blue). CSF vaccines were administered at Day 0 (when 56-59 days old). ALA/SFC or control was administered once a day during Day-4 to Day28. 
The mean daily increase in the body weight of each animal is shown in Table 4. The mean rate of body weight increase for four pigs in the control group was 0.077 $\mathrm{kg} /$ day for the first half of the administration period (Day 11 to Day 10) and was $0.049 \mathrm{~kg} /$ day for the second half (Day 10 to Day 28). In the 5-ALA group, the mean rate of body weight increase for the first half of the administration period was $0.082 \mathrm{~kg} /$ day and that for the second half was 0.064 $\mathrm{kg} /$ day. Therefore, the rates of body weight increase in the $5-A L A$ group were $106 \%$ and $130 \%$ of those in the control group during the first and second halves of the administration period, respectively. This indicated that administration of 5-ALA accelerated the increase in body weight.

Table 4. Average daily weight gain for each pig

\begin{tabular}{|c|c|c|c|c|}
\hline & \multicolumn{4}{|c|}{ Average daily weight gain $[\mathrm{kg}]$} \\
\hline & & Day-11 to Day10 & Day10 to Day28 & Day-11 to Day28 \\
\hline \multirow[t]{6}{*}{ Control } & 4529 & 0.086 & 0.044 & 0.067 \\
\hline & 4530 & 0.086 & 0.050 & 0.069 \\
\hline & 4534 & 0.071 & 0.053 & 0.063 \\
\hline & 4537 & 0.067 & 0.039 & 0.054 \\
\hline & Mean & 0.077 & 0.047 & 0.063 \\
\hline & & $100 \%$ & $100 \%$ & $100 \%$ \\
\hline \multirow[t]{6}{*}{ ALA/SFC } & 4528 & 0.048 & 0.078 & 0.062 \\
\hline & 4533 & 0.081 & 0.061 & 0.072 \\
\hline & 4535 & 0.102 & 0.064 & 0.085 \\
\hline & 4536 & 0.098 & 0.039 & 0.071 \\
\hline & Mean & 0.082 & 0.060 & 0.072 \\
\hline & & $106 \%$ & $130 \%$ & $114 \%$ \\
\hline
\end{tabular}

Day 0: Vaccination

Italics indicate the ratio of the mean value of the ALA/SFC administration group when the average value of the control group was set to $100 \%$.

\section{DISCUSSION}

The current study was conducted in an effort to identify health foods capable of preventing viral infections. Bach2 has been shown to regulate the connected processes of heme transport, degradation, and processing of the degradation byproducts, besides its effects on natural and acquired immunity [12], thereby suggesting the possibility of developing a new cooperative system linking metabolism and immunity. Based on this background, 5-ALA, which is involved in heme synthesis, could advantageously promote viral elimination. In an effort to predict the infection-preventive effects of 5-ALA in humans, microminiature pigs were used in this study, since this animal model can be used to easily extrapolate human equivalent doses [13-14]. Using needleinoculation of a CSF live vaccine, the possibility of 5-ALA manifesting antiviral properties was investigated by examining its effects on antibody production, which forms an important part of the infection establishment process. 
In an effort to simulate its infection-preventive use in humans, 5-ALA administration was initiated prior to vaccine inoculation in this study. In the first experiment, the response to the live CSF vaccine was found to be different in males and females. In the female control group (5-ALA non-administered group), the CSF virus was not detected in the blood, and none of the control females showed antibody production. Surprisingly, when females inoculated with live CSF vaccines received 5-ALA in their feed for one month, antibody production was successfully induced. This tendency continued for up to two weeks after the end of the 5-ALA treatment. This immune response corresponded with an increase in IL-4 and IL-10 levels.

In the male control group, CSF virus was detected even 14 days after vaccination, suggesting that males are more susceptible to the virus than females. However, in contrast to the females, 5-ALA administration in males did not show an apparent effect on antibody production. Nevertheless, the levels of both IL-4 and IL-10 tended to be higher in the 5-ALA administration groups. Therefore, $\lg G$ and $\operatorname{lgM}$ were separately examined for antibody production in males in the next experiment.

Surprisingly, although the pigs from the control group produced both IgM and IgG antibodies, those from the 5-ALA group produced only IgM antibodies. This suggested that even when live virus injection established infection in the pigs, the switch from IgM to IgG did not occur. The phenomenon of class switching is as follows: naive $B$ cells express IgM antibodies on the surface of their cell membranes; upon activation, a DNA recombination reaction known as "class switching" occurs in the constant region of globulin genes, causing $B$ cells to express either IgG or IgA. There are other cells that do not undergo class-switch recombination, and rather differentiate into plasma cells, which then secrete IgM antibodies. Finally, identification of mitochondrial reactive oxygen species (mROS) as a heme synthesis regulator can further enhance the understanding of mechanisms regulating heme homeostasis and cell-fate determination after B-cell activation [15]. Moreover, heme can bind to Bach2, a transcription factor essential for humoral immunity, including antibody class switching.

Watanabe-Masui et al. [16] reported that heme inhibited the DNA-binding activity of Bach2 in vitro and reduced its half-life in $B$ cells. Further, when added to $B$ cell primary cultures, heme enhanced the transcription of Blimp-1, the master regulator of plasma cells, and skewed plasma cell differentiation toward the IgM isotype, decreasing the IgG levels in parallel [16].

Thus, it is possible that administration of 5-ALA promoted heme synthesis, which induced the differentiation of $B$ cells into plasma cells, thereby selectively increasing the levels of IgM antibodies only. In humans, the Nef auxiliary protein of HIV-1 has been reported to inhibit Ig class-switching [17]. Recently, an increased level of antibody production in patients infected with SARS-CoV-2 has been reported, but changes in antibody features and their mechanisms have not yet been fully elucidated [18].

This study utilized the increase in antibody levels in response to the administration of the live vaccine to demonstrate infection establishment. Since the administration of 5-ALA to pigs has been shown to advantageously affect growth and protect against infection [19], the growth of pigs that did and did not receive 5-ALA during this trial were compared with reference to a standard growth curve. Compared to the control group, the 5-ALA group demonstrated a slowly accelerating increase in weight. This result aligned with results of previous reports, indicating that 5-ALA positively affected the growth and immunocompetence of other species of livestock [20-22]. 
Healthy individuals are believed to benefit from the daily use of 5-ALA, which could prevent infection from several aspects. 5-ALA can aid in replacing functionally degraded heme proteins with new ones, thereby helping the maintenance of various redox reactions regulated by heme at a higher level. Infectious diseases often affect many patients in subclinical ways; if the ability to synthesize heme is maintained at a high level and the immune strength is also maintained properly, the body will be quite capable of eliminating viruses naturally, and the preventive use of 5-ALA would boost this capacity further. By contrast, if the ability of the body to synthesize heme drops below a certain level, viruses cannot be eliminated, thereby requiring more heme, eventually pulling the body into a vicious cycle of heme deficiency. The low body-temperature state, often observed in the early stages of viral infection (before fever onset), is caused by heme deficiencies owing to limited thermogenesis, and febrile symptoms may indeed be the result of the imbalanced distribution of body resources for heat production as an emergency response to cause viral elimination. It is worthwhile saying that 5-ALA is safe and effective for antibody production under administration of CSF live vaccine in pig. Although 5-ALA has been recently shown to be effective against SARS-CoV-2 in vitro [23], its efficacy for COVID-19 patients should be investigated according to the adequate clinical protocol.

\section{CONCLUSION}

This study is a preliminary exploration of the antiviral and preventive effects of 5-ALA; a CSF live-vaccine inoculation model was used, and post-inoculation antibody production was examined to determine the establishment of infection. Although this model differs from experimental infection with the novel coronavirus SARS-CoV-2, the results indirectly reflect the effects of vaccine inoculation on healthy individuals receiving 5-
ALA, which is considered to be a health-promoting compound.

Although the measurement of IgM and IgG antibody production did reveal the establishment of infection, the administration of 5-ALA promoted heme synthesis, halting class switching to IgG, thereby inducing the reversal of $B$ cells to plasma cells, ultimately causing elimination of the virus. Recent reports have indicated angiotensin converting enzyme 2 (ACE2) as the receptor through which SARS-CoV-2 infiltrates the host cells [2426]. PPIX is believed to adhere to ACE2 and prevent the binding of SARS-CoV-2 spike proteins [27]; high-dose administration of ALA, which causes PPIX production, has demonstrated remarkable efficiency in this regard. Thus, this suggests that 5-ALA might have the ability to prevent other infections beyond CSF virus infection.

It is necessary to determine the human equivalent dose of health foods such as 5-ALA by evaluating their secondary pharmacological effects other than the antiviral effect using experimental pigs, which are similar to humans in terms of body size and metabolism [28]. Although 5-ALA was shown to be effective against SARSCoV-2 in vitro [23], its efficacy for COVID-19 patients should be investigated further.

List of Abbreviations: ACE2: angiotensin converting enzyme 2, CSF: classical live swine fever, HED: Human Equivalent Dose, MMP: micro miniature pigs, mROS: mitochondrial reactive oxygen species, PPIX: protoporphyrin IX, 5-ALA: 5-aminolevulinic acid.

Authors Contribution: Study concept and design, performing experiments, analysis and interpretation of data, drafting of the manuscript, revision of the manuscript and statistical analysis: Eiji Kobayashi

Conflict of Interest: Eiji Kobayashi is a medical advisor of Neophama Japan Co., Ltd. 
Acknowledgements: CSF live-vaccine inoculation was performed by Kouji Dobashi (Eastern Yamanashi Animal Health Center), and measurement of the levels of antiCSF virus IgG and IgM antibodies was performed by Dr. Noriaki Imaeda (Gifu University Faculty of Veterinary Medicine). Further, Kiyotaka Fujine (Neopharma Japan Co., Ltd., Tokyo, Japan), Motowa Nakajima and Tohru

\section{REFERENCES}

1. Suzuki H, Masuki S, Morikawa A, Ogawa Y, Kamijo YI, Takahashi $K$, Nakajima $M$ et al.: Effects of 5-aminolevulinic acid supplementation on home-based walking training achievement in middle-aged depressive women: randomized, double-blind, crossover pilot study. Sci Rep. 2018, 8(1):7151.

https://doi.org/10.1038/s41598-018-25452-2.

2. Rehani PR, Iftikhar $H$, Nakajima M, Tanaka T, Jabbar Z, Rehani RN et al.: Safety and Mode of Action of Diabetes Medications in comparison with 5-Aminolevulinic Acid (5-ALA). J Diabetes Res. 2019, 4267357. https://doi.org/10.1155/2019/4267357.

3. Smith TG, Kain KC: Inactivation of Plasmodium falciparum by photodynamic excitation of heme-cycle intermediates derived from delta-aminolevulinic acid. J Infect Dis. 2004, 190(1):184191. https://doi.org/10.1086/421503.

4. Suzuki S, Hikosaka K, Balogun EO, Komatsuya K, Niikura M, Kobayashi $\mathrm{F}$ et al: In vivo curative and protective potential of orally administered 5-aminolevulinic acid plus ferrous ion against malaria. Antimicrob Agents Chemother. 2015, 59(11):6960-6967. https://doi.org/10.1128/aac.01910-15.

5. Calvo EP, Wasserman M: G-Quadruplex ligands: Potent inhibitors of telomerase activity and cell proliferation in Plasmodium falciparum. Mol Biochem Parasitol. 2016, 207(1):33-38.

https://doi.org/10.1016/j.molbiopara.2016.05.009.

6. Ruggiero E, Richter SN: G-quadruplexes and G-quadruplex ligands: targets and tools in antiviral therapy. Nucleic Acids Res. 2018, 46(7):3270-3283. https://doi.org/10.1093/nar/gky187

7. Pedrosa-Gerasmio IR, Kondo H, Hirono I: Molecular cloning, characterization and gene expression analysis of aminolevulinic acid synthase in Litopenaeus vannamei. Gene 2020, 736:144421. https://doi.org/10.1016/j.gene.2020.144421.

8. Wu F, Zhao S, Yu B, Chen YM, Wang W, Song ZG, Hu Y, et al: A new coronavirus associated with human respiratory disease in China. Nature. 2020, 579(7798):265-269.
Tanaka (SBI Pharmaceuticals Co., Ltd., Tokyo, Japan) assisted in the preparation of this manuscript.

Funding: This work was supported by Neopharma Japan Co., Ltd. The funder had no role in the study design; in the collection, analysis, and interpretation of data; in the writing of the report; and in the decision to submit the article for publication.

\section{https://doi.org/10.1038/s41586-020-2008-3.}

9. Pickering BS, Smith G, Pinette MM, Embury-Hyatt C, Moffat E, Marszal P, et al: Susceptibility of Domestic Swine to Experimental Infection with Severe Acute Respiratory Syndrome Coronavirus 2. Emerg Infect Dis. 2021, 27(1):104-112. https://doi.org/10.3201/eid2701.203399

10. T Opriessnig T, Huang YW: Coronavirus disease 2019 (COVID-19) outbreak: Could pigs be vectors for human infections? Xenotransplantation. 2020, 27(2): e12591. https://doi.org/10.1111/xen.12591.

11. Kobayashi E: Viral infections of pigs used for medical education. A Japanese experience. Acta Cir Bras. 2020, 35(8):e202000808. https://doi.org/10.1590/s0102-865020200080000008.

12. Edwards $\mathrm{CL}$, de Oca $\mathrm{MM}$, de Labastida Rivera F, Kumar R, Ng SS, Wang $\mathrm{Y}$, Amante $\mathrm{FH}$, et al: The Role of $\mathrm{BACH} 2$ in $\mathrm{T}$ Cells in Experimental Malaria Caused by Plasmodium chabaudi chabaudi AS. Front Immunol. 2018, 9:2578. https://doi.org/10.3389/fimmu.2018.02578.

13. Nair $A B$, Jacob $S: A$ simple practice guide for dose conversion between animals and humans. J Basic Clin Pharm. 2016, 7(2):2731. https://doi.org/10.4103/0976-0105.177703.

14. Tohyama S, Kobayashi E: Age-Appropriateness of Porcine Models Used for Cell Transplantation. Cell Transplant. 2019, 28(2):224-228. https://doi.org/10.1177/0963689718817477.

15. Jang KJ, Mano H, Aoki K, Hayashi T, Muto A, Nambu Y, Takahashi $\mathrm{K}$ et al: Mitochondrial function provides instructive signals for activation-induced B-cell fates. Nat Commun. 2015, 6:6750. https://doi.org/10.1038/ncomms7750.

16. Watanabe-Matsui $M$, Muto $A$, Matsui $T$, Itoh-Nakadai $A$ Nakajima O, Murayama K, Yamamoto $\mathrm{M}$ et al: Heme regulates Bcell differentiation, antibody class switch, and heme oxygenase1 expression in B cells as a ligand of Bach2. Blood. 2011, 117(20):5438-5448. https://doi.org/10.1182/blood-2010-07-296483.

17. Qiao X, He B, Chiu A, Knowles DM, Chadburn A, Cerutti A: Human 
immunodeficiency virus 1 Nef suppresses CD40-dependent immunoglobulin class switching in bystander B cells. Nat Immunol. 2006, 7(3):302-310. https://doi.org/10.1038/ni1302.

18. Gudbjartsson DF, Norddahl GL, Melsted P, Gunnarsdottir K, Holm H, Eythorsson E, Arnthorsson AO, et al: Humoral Immune Response to SARS-CoV-2 in Iceland. N Engl J Med. 2020, 383(18):1724-1734. https://doi.org/10.1056/NEJMoa2026116.

19. Chen YJ, Kim IH, Cho JH, Min BJ, Yoo JS, Wang Q: Effect of $\delta$ aminolevulinic acid on growth performance, nutrient digestibility, blood parameters and the immune response of weanling pigs challenged with Escherichia coli lipopolysaccharide. Livest. Sci.2008, 114: 108-116. https://doi.org/10.1016/j.livsci.2007.04.015

20. Wang JP, Kim HJ, Chen YJ, Yoo JS, Cho JH, Kang DK, Hyun Y, et al: Effects of delta-aminolevulinic acid and vitamin C supplementation on feed intake, backfat, and iron status in sows. J. Anim. Sci. 2009, 87: 3589-3595.

https://doi.org/10.2527/jas.2008-1489.

21. Sato K, Matsushita K, Takahashi K, Aoki M, Fuziwara J, Miyanari S, Kamada T: Dietary supplementation with 5-aminolevulinic acid modulates growth performance and inflammatory responses in broiler chickens, Poultry Sci. 2012, 91:1582-1589. http://dx.doi.org/10.3382/ps.2010-01201.

22. Hendawy AO, Shirai M, Takeya H, Sugimura S, Miyanari S, Taniguchi S, Sato K: Effects of 5-aminolevulinic acid supplementation on milk production, iron status, and immune response of dairy cows, J. Dairy Sci. 2019, 102:11009-11015.

https://www.journalofdairyscience.org/article/S00220302(19)30860-4/fulltext

23. Sakurai Y, Ngwe Tun MM, Kurosaki Y, Sakura T, Inaoka DK, Fujine K, Kita K, et al: 5-amino levulinic acid inhibits SARS-CoV-2 infection in vitro. Biochem Biophys Res Commun. 2021, 45:203207. https://doi.org/10.1016/j.bbrc.2021.01.091.

24. Wan Y, Shang J, Graham R, Baric RS, Li F: Receptor Recognition by the Novel Coronavirus from Wuhan: an Analysis Based on Decade-Long Structural Studies of SARS Coronavirus. J Virol. 2020, 94(7):e00127-20. https://doi.org/10.1128/JVI.00127-20.

25. Zhou P, Yang XL, Wang XG, Hu B, Zhang L, Zhang W, Si HR, et al: A pneumonia outbreak associated with a new coronavirus of probable bat origin. Nature. 2020, 579(7798):270-273. https://doi.org/10.1038/s41586-020-2012-7

26. Letko M, Marzi A, Munster V: Functional assessment of cell entry and receptor usage for SARS-CoV-2 and other lineage B beta coronaviruses. Nat Microbiol. 2020, 5(4):562-569.

https://doi.org/10.1038/s41564-020-0688-y.
27. Gu C, Wu Y, Guo H, Zhu Y, Xu W, Wang Y, Zhou Y, et al: Protoporphyrin IX and verteporfin potently inhibit SARS-CoV-2 infection in vitro and in a mouse model expressing human ACE2. Sci Bull (Beijing). 2021, 66(9):925-936. https://doi.org/10.1016/j.scib.2020.12.005.

28. Kobayashi E: Testing of human equivalent dose of health food 5aminolevulinic acid using the experimental pig. Biomed Pharmacother. 2021, 139:111629. https://doi.org/10.1016/j.biopha.2021.111629. 